\title{
ERRATUM
}

T. Komatsuda $\cdot$ P. Maxim $\cdot$ N. Senthil $\cdot$ Y. Mano

\section{High-density AFLP map of nonbrittle rachis 1 (btr1) and 2 (btr2) genes in barley (Hordeum vulgare L.)}

Published online: 13 November 2004

(c) Springer-Verlag 2004

\section{Theor Appl Genet (2004) 109:986-995}

The present addresses of the authors, listed here, were not indicated correctly in the print version of this article. The online version is correct.

The online version of the original article can be found at http:// dx.doi.org/10.1007/s00122-004-1710-0

T. Komatsuda $(\bowtie) \cdot$ P. Maxim $\cdot$ N. Senthil $\cdot$ Y. Mano

National Institute of Agrobiological Sciences,

Tsukuba 305-8602, Japan

E-mail: takao@affrc.go.jp

Tel.: + 81-29-838-7482

Fax: + 81-29-838-7408

Present address: P. Maxim

Research Institute for Cereals and Industrial Crops,

Fundulea, 8264, Romania

Present address: N. Senthil

Centre for Plant Breeding and Genetics,

Tamil Nadu Agricultural University,

Coimbatore, 641041, India

Present address: Y. Mano

National Institute of Livestock and Grassland Science,

Nishinasuno 329-2793, Japan 